\title{
Human Capital and Energy Efficiency: Evidence from Developing Countries
}

\author{
Bless Kofi Edziah1, Huaping Sun ${ }^{*}$, Emmanuel Anyigbah², Liang Li ${ }^{3}$ \\ ${ }^{1}$ Institute of Industrial Economics, Jiangsu University, Zhenjiang, China \\ ${ }^{2}$ School of Finance and Economics, Jiangsu University, Zhenjiang, China \\ ${ }^{3}$ School of Business, Nanjing University of Information Science and Technology, Nanjing, China \\ Email: *shp797@163.com
}

How to cite this paper: Edziah, B. K., Sun, H., Anyigbah, E., \& Li, L. (2021). Human Capital and Energy Efficiency: Evidence from Developing Countries. American Journal of Industrial and Business Management, 11, 599-610.

https://doi.org/10.4236/ajibm.2021.116038

Received: April 30, 2021

Accepted: June 4, 2021

Published: June 7, 2021

Copyright (c) 2021 by author(s) and Scientific Research Publishing Inc. This work is licensed under the Creative Commons Attribution International License (CC BY 4.0).

http://creativecommons.org/licenses/by/4.0/

\begin{abstract}
This study explores the effect of human capital on energy efficiency in a panel of developing countries from 1990 to 2017. Using the stochastic frontier model and the energy demand function, our results show that human capital can increase energy efficiency. Even after controlling for certain factors, the variable for human capital result remains unchanged. With regards to the controls, green innovation increased energy efficiency, while institutional quality showed an insignificant relation with energy efficiency. In general, the research results show that one essential positive externality of human capital development is that it promotes a greener future through energy conservation. Our findings can provide policymakers and governments with good reasons why more attention should be paid to human capital development to stimulate energy efficiency and a green future.
\end{abstract}

\section{Keywords}

Human Capital, Energy Efficiency, Stochastic Frontier Analysis, Energy Demand Function

\section{Introduction}

As the population of developing countries grows, energy demand will increase accordingly, thereby further exacerbating the climate change problem. For these countries, measures to address climate change and sustainability often focus on reducing the use of dirty energy sources such as coal and oil (Rafindadi, 2016; Sun et al., 2020b; Wang \& Li, 2016). However, promoting and supporting green technological innovation, (such as smart climate infrastructure and design, and low-carbon and energy-efficient transportation systems) are often more sus- 
tainable; and this requires high levels of human capital development and capacity building (Yao et al., 2019).

Human capital is regarded as the foundation of any country's progress. The initiative to promote ground-breaking development falls on the shoulders of the human resources of a country (Sun et al., 2019). Supporting this view is the endogenous growth model which emphasized that human capital accumulation will eventually contribute to production, which will create economic growth (Romer, 1990, 1994). Similarly, because of the elevated incidence of environmental degradation in recent years and the consequent climate change issues, the role of human resources or education in combating climate change has become apparent in the literature in recent years (Sarkodie et al., 2020). Therefore, at the micro-level, there are sherds of evidences that well-educated members of households are much more ecologically and energy conscious, and, as a result, spend less energy (Çelik \& Oktay, 2019; Jin et al., 2019; Zhang \& Kotani, 2012; Mbaka et al., 2016; Narasimha, Rao, \& Reddy, 2007). Similarly, there is evidence that companies with well-educated, well-trained, and skilled executives and employees are much more energy efficient (Chai \& Baudelaire, 2015; He \& Huang, 2020).

However, from the macro perspective, the effect of human capital development on energy efficiency is a bit unclear. First, there is a paucity of empirical research on the link between human capital and macro-energy efficiency (Solarin, 2020). The second reason is that, although human capital can increase energy efficiency by stimulating energy-saving innovation, it is also possible that human capital will increase energy usage and reduce efficiency due to its role in promoting economic growth (Greening et al., 2000; Li \& Lin, 2018). In addition, in the production process, human capital can substitute or complement other energy inputs economy (Carraro et al., 2014; Fan et al., 2007).

Empirically speaking, many studies have explored the factors of energy efficiency improvement, but limited number of research have studied the impact of human capital on improving energy efficiency, especially in developing countries. Huang et al. (2018) studied the relationship between the technology spillover effect of Foreign Direct Investment (FDI) and energy intensity and established that human capital stock has a positive influence on enhancing the positive technology spillover effect of FDI on energy intensity in terms of absorbing and using the technology embodied in FDI. Li et al. (2019) explored whether FDI will enhance the convergence of energy intensity among Chinese provinces and whether local characteristics will lead to such convergence. Their observation is that human capital helps to absorb foreign direct investment in advanced technology, which helps in reducing energy intensity. Huang and Chen (2020) studied the relationship between China's domestic R\&D activities, technology absorptive capacity and energy intensity. Their results show an increase in human capital stock reduces the negative impact on increasing energy intensity. In an attempt to link energy to economic progress, Pablo-Romero and Sánchez- 
Braza (2015) observed that education could reduce energy consumption, that is, the more training workers receive, the more efficient the use of material capital, which means the less energy is used. Solarin (2020) studied the factors affecting energy intensity in developing countries and found that human capital development can lead to the spread, awareness and adoption of energy-saving technologies. Sequeira and Santos (2018) explored the link between education and energy intensity and found that education can help reduce energy intensity. Yao et al. (2019) studied the impact of human capital stock on energy use in OECD countries from 1965 to 2014 and they observe that human capital stock decreases total energy usage by $15.36 \%$. Salim et al. (2017) used China's provincial data from 1990 to 2010 to analyze the dynamic correlation between human capital and consumption of energy. They observed that for every $1 \%$ growth in human capital, energy use would decrease by $0.18 \%$ to $0.45 \%$. Using data from the Organization for Economic Cooperation and Development (OECD) member countries from 1980 to 2015, Alvarado et al. (2021) studied whether economic development and human capital reduced the consumption of non-renewable energy. Their findings recommend that improving human capital stock reduces nonrenewable energy usage.

We differ from the above studies in two aspects. For starters, they are more concerned with the effect of human capital on energy consumption (Alvarado et al., 2021; Pablo-Romero \& Sánchez-Braza, 2015; Salim et al., 2017; Yao et al., 2019) or energy intensity (Huang et al., 2018; Huang \& Chen, 2020; Li et al., 2019; Sequeira \& Santos, 2018) than with the effect of human capital on energy efficiency. The commonly used measure in energy estimation is the energy intensity measure (that is, the ratio of energy to gross domestic product (GDP)). As a result, energy intensity indicators are frequently mistaken for energy efficiency measures. However, according to IEA (2009), using energy intensity indicators as energy efficiency measurements may not be completely correct because it needs strong assumptions about efficiency-related factors. For instance, energy efficiency is influenced by factors unrelated to energy. Therefore, using energy intensity as a measure of energy efficiency could be misleading. This is because it ignores behavioral and structural differences between countries (such as technological and economic structure, demographics, lifestyle, and climatic conditions) (Lundgren et al., 2016). Second, in most cases, their focus is not to study the correlation between human capital and energy efficiency, but rather somewhere in-between the analysis, a human development index is introduced as a control variable.

Based on the above assertion, we aim to add to the existing literature on the connection between human capital and energy efficiency at the macro perspective by focusing solely on 10 major energy-consuming developing countries around the world (i.e. China, Iran, South Africa, Nigeria, Indonesia, India, Mexico, Brazil, Russia, Turkey and Ukraine). According to EIA (2007), the energy demand is expected to increase considerably in the coming years in developing 
countries (i.e. from $46 \%$ to $58 \%$ between 2004 to 2040) and these countries will play a major role in this increase. To get rid of the concept of "grow now, clean up later", it is urgent to assess what factors can improve energy efficiency in developing countries and in our case the aim is to assess the role of human capital on energy and environmental sustainability. Therefore, our study focuses on examining how important human capital is to energy efficiency improvement using the stochastic frontier analysis (SFA).

In order to conduct this research, the remainder of this article is organized in the following manner: Section 2 presents the data and methods. Section 3 discusses the findings, and Section 4 concludes by highlighting main findings and providing policy recommendations.

\section{Data and Methodology}

\subsection{Data}

This research collated an annual frequency data series of 10 developing countries spanning 1990-2017. Owing to the unavailability of data, we limit our sample to the following 10 energy consuming developing countries: China, Iran, South Africa, Nigeria, Indonesia, India, Mexico, Brazil, Russia, Turkey and Ukraine. As mentioned earlier, these developing countries are among the top global energy consumers. Additionally, compare to the other developing countries, these countries have a high stock of human capital. Therefore, these countries' educational standards, as well as their labor force are superior to the other the developing countries. Table 1 illustrates the data used in this research, its source and the unit of measure.

\subsection{Methodology}

As said earlier, in this article, the stochastic frontier method is adopted to calculate

Table 1. Source of data and unit of measure.

\begin{tabular}{cccc}
\hline Variables & Acronyms & Unit & Source \\
\hline Gross Domestic Product & GDP & Constant 2010 US dollar & PWT database \\
Energy price & EP & $\begin{array}{c}\text { Price of Crude oil in US\$ per } \\
\text { barrel deflated by country's } \\
\text { consumer price index }\end{array}$ & $\begin{array}{c}\text { BP statistical Review } \\
\text { of World Energy }\end{array}$ \\
Population density & PD & Total population & \\
Urbanization & URB & \% of total population & WDI database \\
Share of service sector value & SS & \% of GDP & WDI database \\
Human Capital & HC & Index & WDI database \\
Green innovation & GP & Patent count & PWT database \\
Institutional quality & IQ & Index & OECD database \\
\hline
\end{tabular}

PWT: Penn World Tables (Feenstra et al., 2015); WDI: World Development Indicator; OECD: Organization for Economic Co-operation and Development library. 
the total frontier energy demand function. In energy economics, energy efficiency is largely viewed as using less energy input to produce greater or the same level of economic output. As a result, this method treats energy as a factor of production that is combined with other inputs to provide energy services, with the goal of estimating inefficiency in the utilisation of input energy as a (positive) deviation from an energy demand frontier function. Generally, the aggregate energy demand for country $i$ at a time $t$ can be expressed as:

$$
E D_{i t},=f\left(P_{i t}, Y_{i t}, X_{i t}\right)+v_{i t}
$$

where $E D_{i t}$ denotes aggregate energy demand, $Y_{i t}$ is the real income, $P_{i t}$ is the real energy price, and $X_{i t}$ is a set of control variables (like level of urbanization, population, industrialization or time dummies). The last term $v_{i t}$ captures the random noise which is assumed to be symmetrically identical and usually distributed with a mean of zero and variance, that is. $v \sim N\left(0, \sigma_{v}^{2}\right)$.

A Cobb-Douglas (CD) function is assumed here, as it is in most energy demand models. Therefore, introducing the natural logarithm of variables as well as the country specific fixed effects $\alpha_{j}$, this results in the following estimable linear function:

$$
\ln E D_{i t},=\alpha_{0}+\ln \beta_{1} P_{i t}+\ln \beta_{2} Y_{i t}+\ln \psi X_{i t}+\alpha_{j}+v_{i t}
$$

Filippini and Hunt (2012) extended the energy demand function in Equation (2) by modelling "energy consumption efficiency" using the stochastic frontier approach. Therefore, Equation (2) is expanded with another term $u_{i}$ whose aim is to mirror the degree of inefficiency. The term $u_{i}$ is a non-negative error term which is often considered to have a half-normal distribution as in Aigner et al. (1977), that is $u \sim N^{+}\left(0, \sigma_{u}^{2}\right)$. It encapsulates inefficiency, which is how much more energy a country consumes beyond that which is deemed "necessary." In other words, it indicates the shortfall of the country's output from the efficient frontier. The $X_{i t}$ vector, in this study comprises of the effects of population density (PD), urbanization (URB) and value added by the service sector as a share of GDP (Serv). The effect of demography is captured by urban growth and population density. Changes in economic structure are captured by the value added by the service sector. The resulting econometric formulation can be stated as:

$$
\begin{aligned}
\ln E D_{i t},= & \alpha_{0}+\ln \beta_{1} P_{i t}+\ln \beta_{2} Y_{i t}+\ln \beta_{3} \mathrm{PD}_{i t}+\ln \beta_{4} \mathrm{URB}_{i t} \\
& +\ln \beta_{5} \operatorname{Serv}_{i t}+\alpha_{j}+v_{i t}+\mu_{i t}
\end{aligned}
$$

The conventional stochastic frontier method defined in Aigner et al. (1977) can be used to estimate this specification. However, many scholars have made a criticism of this specification, that is, inefficiency $u_{i}$ is simply a half-normal stochastic process, so the efficiency score derived from this model may not be meaningful. In order to alleviate this concern, here we estimate the inefficiency using the model suggested by Battese and Coelli (1995) which uses some additional predetermined variables in the vector $z_{i}$ to estimate the average inefficiency level. Therefore, following Battese and Coelli (1995) the inefficiency term 
$\mu_{i t}$ in Equation (3) is adjusted to have some additional predetermined variables of vector $z_{i}$ and a random component $\left(e_{i t}\right)$ :

$$
u_{i t}=z_{i t}+e_{i t}
$$

These predetermined variables include our main variable of human capital as well as some control variables (that is, green technology and institutional quality). Here, we assume that the use of less energy inputs to produce a much larger or same level of economic output is dependent not just on the tool's energy efficiency but also the technical expertise of the labor. For example, a relatively new and advanced machinery operated by a skilled labor offers a smooth production process, which is able to offer same level of service using less energy. Therefore, to illustrate these parts, energy inefficiency average $u_{i t}$ is defined as

$$
u_{i t}=\beta_{o}+\beta_{H} \mathrm{HC}_{i t}+\beta_{c} \operatorname{Con}_{i t}
$$

where $\beta$ is the estimated parameter, $\mathrm{HC}_{i t}$ is the human capital index, and Con $_{i t}$ are the control variables.

Numerous models could be utilized to estimate a panel data stochastic frontier model (Filippini et al., 2014). In this research, given that the focus is to assess the effect of human capital index on energy efficiency performance, a panel data stochastic frontier model which allows energy efficiency levels to vary over time and depends on a set of covariates is adopted. Therefore, this study adopts the true fixed effects model proposed by Greene (2005). This method can be used to estimate stochastic frontier models in which the efficiency level is a function of explanatory variables ${ }^{1}$.

\section{Results and Discussion}

\section{Estimated Energy Demand Model}

Table 2 shows the estimated results of the aggregate energy demand model using the true fixed effect SFA methods. From the energy demand function, the price of energy has a significant negative impact on energy demand in model (1). However, after introducing the control variables in model (2)-(4), the estimated price coefficient change to positive. Though the results in model (2)-(4) are contrary to theoretical expectations, in the context of a developing economy this can be attributed to fuel subsidies. According to Adom et al. (2018), fossil fuel subsidy reduces the price at which consumer buys fuel and therefore diminishes the sensitivity of consumption to price fluctuations. This outcome is similar to those found by Adom et al. (2018).

However, in all three models, the estimated income elasticity is positive and significant. The positive effect of income demonstrates that increased incomes in developing economies have a larger scale effect than technical effects, which is similar to results of Adom et al. (2018); Sineviciene et al. (2017); Filippini and Zhang (2016); Sun et al. (2020a).

Population density shows a positive and significant effect on energy demand in

${ }^{1}$ See Greene (2005) and Filippini et al. (2014) on details on the true fixed effect method. 
Table 2. Estimated aggregate energy demand function.

\begin{tabular}{|c|c|c|c|c|}
\hline Energy Demand Function & Model (1) & Model (2) & Model (3) & Model (4) \\
\hline \multirow[t]{2}{*}{$\ln P$} & $-0.0102^{\star}$ & $0.0743^{* * *}$ & 0.00780 & $0.0611^{\star * \star}$ \\
\hline & $(0.00612)$ & $(0.0168)$ & $(0.0145)$ & $(0.0190)$ \\
\hline \multirow[t]{2}{*}{$\ln G D P$} & $0.559^{* * *}$ & $0.876^{* * *}$ & $0.721^{* * *}$ & $0.847^{* * *}$ \\
\hline & $(0.0403)$ & $(0.00941)$ & $(0.114)$ & $(0.00971)$ \\
\hline \multirow[t]{2}{*}{$\ln P D$} & $0.966^{* * *}$ & $-0.612^{\star * *}$ & $-0.446^{* * *}$ & $-0.667^{* * *}$ \\
\hline & $(0.103)$ & $(0.0235)$ & $(0.0355)$ & $(0.0236)$ \\
\hline \multirow[t]{2}{*}{$U r b$} & $0.00783^{* * *}$ & $-0.0385^{\star * *}$ & -0.0201 & $-0.0409^{* * *}$ \\
\hline & $(0.00277)$ & $(0.00340)$ & $(0.0203)$ & $(0.00315)$ \\
\hline \multirow[t]{2}{*}{ Serv } & $-0.00879^{\star * *}$ & $-0.0135^{\star * *}$ & $-0.0235^{\star * *}$ & $-0.0158^{\star * *}$ \\
\hline & $(0.00210)$ & $(0.00477)$ & $(0.00813)$ & $(0.00446)$ \\
\hline \multirow[t]{2}{*}{$T$} & $-0.0131^{* * *}$ & $0.0232^{* * *}$ & $0.0173^{\star *}$ & $0.0270^{* * *}$ \\
\hline & $(0.00206)$ & $(0.00224)$ & $(0.00694)$ & $(0.00232)$ \\
\hline \multicolumn{5}{|l|}{ Inefficiency Function } \\
\hline \multirow[t]{2}{*}{$\ln H C$} & $-10.98^{\star * *}$ & $-9.472^{\star *}$ & $-13.64^{* * *}$ & $-7.780^{*}$ \\
\hline & $(1.783)$ & $(4.324)$ & $(3.876)$ & $(4.612)$ \\
\hline \multirow[t]{2}{*}{$\ln P a t$} & & $-0.864^{\star *}$ & & $-0.908^{\star *}$ \\
\hline & & $(0.375)$ & & $(0.442)$ \\
\hline \multirow[t]{2}{*}{ InInsti } & & & -0.979 & -3.107 \\
\hline & & & $(3.396)$ & $(3.669)$ \\
\hline \multirow[t]{2}{*}{ Usigma } & $2.080^{* *}$ & 1.528 & 4.445 & 5.442 \\
\hline & $(0.924)$ & $(1.734)$ & $(4.467)$ & $(5.231)$ \\
\hline \multirow[t]{2}{*}{ Vsigma } & $-5.641^{\star * *}$ & $-4.224^{\star * *}$ & $-4.333^{* * *}$ & $-4.170^{\star * *}$ \\
\hline & $(0.145)$ & $(0.134)$ & $(0.443)$ & $(0.127)$ \\
\hline Observations & 241 & 185 & 223 & 183 \\
\hline Number of id & 10 & 9 & 10 & 9 \\
\hline
\end{tabular}

Notes: Coefficient being significant at $1 \%$ is denoted as $\left({ }^{* *}\right), 5 \%\left({ }^{* *}\right)$ and $10 \%\left({ }^{*}\right)$.

model (1) however after controlling for the effect of green innovation and government institution in model (2)-(4), the coefficient change to negative. That is, a $1 \%$ growth in population density will result in a drop of $0.44 \%-0.66 \%$ in energy demand. According to Adom et al. (2018), people in densely populated areas usually use non-energy-based transportation means (e.g. bicycles) and lowenergy transportation means (e.g. motorcycles). This supports the results of Filippini and Zhang (2016); Adom et al. (2018); Sun et al. (2020a). Urbanization also has a significant negative effect on energy demand in model (2)-(4), which endorses the findings of Keho (2016) and Adom et al. (2018).

The share of the service sector exhibits a significant negative effect on energy demand in all models. The service industry consumes less energy. Therefore, 
transforming economic structure to the service industry will reduce the total energy needed to carry out economic activities (Adom et al., 2018). Also, the time trend seems to lower energy consumption in model (1), but after introducing the control variables, the results seem to be the opposite in models (2)-(5). One plausible justification for this conclusion, according to Filippini and Hunt (2012), is that various models capture the effect of technological advances on energy efficiency in diverse manners (for example, through price effects, time trends, or inefficient terms).

In view of the focus of this research, we study the effect of human capital development on energy efficiency in the next part of the model. Therefore, in model (1), we started the analysis by introducing only human capital variable in the inefficient function. We discovered that human capital has a significant negative effect on energy inefficiency at a significance level of $1 \%$. Note that a negative coefficient here means that the variable reduces inefficiency items, which means that energy efficiency is improved.

In the subsequent models, that is model (2)-(4), we introduced some controls to test the stability of the human capital results in model (1). Therefore, in model (2), we first control the level of innovation among countries. Even after controlling for this variable, the human capital coefficient is still negative, and the significance level is $1 \%$. When we replace innovation variables with institutional quality variable, the human capital coefficient is still similar to model (3). Also, even after adding the two variables (namely innovation and institutional quality) in model (4), the results of human capital are still completely consistent with models (1)-(3).

The results demonstration that developing human capital enhance energy efficiency. This clarifies why countries that have access to a wide share of workforce in skill-intensive jobs and a high level of education achieve high-income status and better environmental performance (Sarkodie et al., 2020; Sun et al., 2021a). According to Sianesi and Van Reenen (2003), human capital investment has a multitude of beneficial externalities, which includes improved public health, drop in crime rates, and better social cohesiveness. Yao et al. (2019) discovered that human capital creates large positive environmental externalities. As a result, our outcomes back up the notion that investing in human capital has a positive social impact while also pointing to a possible pathway for energy conservation that does not stifle economic progress.

In terms of control variables, as expected, the green innovation coefficient has a significant negative impact on energy inefficiency, which means that the increase in green innovation promotes energy efficiency. This finding is similar to that of Wurlod and Noailly (2018), who discovered that a $0.3 \%$ decrease in energy inefficiency is connected with a percentage rise in green technology. Lin and Moubarak (2014) and Sun et al. (2019) discovered similar results, stating that increasing green technology improves energy efficiency.

However, the variable for institutional quality shows no significant effect on energy efficiency which contradicts those found in Sun et al. (2019) and Sun et 
al. (2021b). Since the quality of institutions in developing countries is weak and relatively weaker compare to developed countries, it is understandable why the quality of institutions seems to contribute less to the improvement of energy efficiency.

\section{Conclusion and Policy Implication}

\subsection{Main Findings}

With the stochastic energy distance frontier model, we use the Greene (2005) fixed effect model with a selection of some environmental factors to study the role of human capital on energy efficiency for a panel of developing countries during the period 1990-2017. The key discovery is that human capital improves energy efficiency, and when we control for other factors in the model, the result of human capital remains the same. Our results show that, for these developing countries, the benefits of human capital on energy efficiency come from the increase in the percentage of employees with higher education. We also found that green innovation plays an important role in improving energy efficiency. The final discovery in relation to the other control variable-institutional quality, is that it has no effect on the energy efficiency performance for these countries.

\subsection{Policy Implications}

From a policy standpoint, energy efficiency is commonly regarded as one of the major policy strategies to reduce greenhouse gas emissions and global warming. However, improving energy efficiency at the firm and country levels remains a major obstacle. Our key outcome on the impact of human capital on energy efficiency indicates that investing in people can help enhance energy efficiency, which indicates that policymakers in these developing countries should pay special attention to investment in higher education to obtain environmental benefits from higher human capital. Because green innovation can improve energy efficiency, the policy direction of strengthening the development and deployment of more green technologies in these countries will help achieve the environmental security stipulated in the sustainable development goals.

Finally, the role of institutional quality showing an insignificant relationship on energy efficiency suggests the institutions in the developing economies should be empowered and supported to act independently without any influences from the government.

\section{Fund}

This work was supported by the Key Program of National Social Science Fund of China (21AZD067).

\section{Conflicts of Interest}

The authors declare no conflicts of interest regarding the publication of this paper. 


\section{References}

Adom, P. K., Amakye, K., Abrokwa, K. K., \& Quaidoo, C. (2018). Estimate of Transient and Persistent Energy Efficiency in Africa: A Stochastic Frontier Approach. Energy Conversion and Management, 166, 556-568. https://doi.org/10.1016/j.enconman.2018.04.038

Aigner, D., Lovell, C. A. K., \& Schmidt, P. (1977). Formulation and Estimation of Stochastic Frontier Production Function Models. Journal of Econometrics, 6, 21-37. https://doi.org/10.1016/0304-4076(77)90052-5

Alvarado, R., Deng, Q., Tillaguango, B., Méndez, P., Bravo, D., Chamba, J., Alvarado-Lopez, M., \& Ahmad, M. (2021). Do Economic Development and Human Capital Decrease Non-Renewable Energy Consumption? Evidence for OECD Countries. Energy, 215, Article ID: 119147. https://doi.org/10.1016/j.energy.2020.119147

Battese, G. E., \& Coelli, T. (1995). A Model for Technical Inefficiency Effects in a Stochastic Frontier Production Function for Panel Data. Empirical Economics, 20, $325-$ 332. https://doi.org/10.1007/BF01205442

Carraro, C., De Cian, E., \& Tavoni, M. (2014). Human Capital, Innovation, and Climate Policy: An Integrated Assessment. Environmental Modeling \& Assessment, 19, 85-98. https://doi.org/10.1007/s10666-013-9385-Z

Çelik, A. K., \& Oktay, E. (2019). Modelling Households' Fuel Stacking Behaviour for Space Heating in Turkey Using Ordered and Unordered Discrete Choice Approaches. Energy Build, 204, Article ID: 109466. https://doi.org/10.1016/j.enbuild.2019.109466

Chai, K. H., \& Baudelaire, C. (2015). Understanding the Energy Efficiency Gap in Singapore: A Motivation, Opportunity, and Ability Perspective. Journal of Cleaner Production, 100, 224-234. https://doi.org/10.1016/j.jclepro.2015.03.064

EIA (Energy Information Administration) (2007). Annual Energy Outlook, DOE/ EIA-O. Washington DC: Energy Information Administration.

Fan, Y., Liao, H., \& Wei, Y. M. (2007). Can Market Oriented Economic Reforms Contribute to Energy Efficiency Improvement? Evidence from China. Energy Policy, 35, $2287-$ 2295. https://doi.org/10.1016/j.enpol.2006.07.011

Feenstra, R. C., Inklaar, R., \& Timmer, M. P. (2015). The Next Generation of the Penn World Table. American Economic Review, 105, 3150-3182. https://doi.org/10.1257/aer.20130954

Filippini, M., \& Hunt, L. C. (2012). US Residential Energy Demand and Energy Efficiency: A Stochastic Demand Frontier Approach. Energy Economics, 34, 1484-1491. https://doi.org/10.1016/j.eneco.2012.06.013

Filippini, M., \& Zhang, L. (2016). Estimation of the Energy Efficiency in Chinese Provinces. Energy Efficiency, 9, 1315-1328. https://doi.org/10.1007/s12053-016-9425-Z

Filippini, M., Hunt, L. C., \& Zorić, J. (2014). Impact of Energy Policy Instruments on the Estimated Level of Underlying Energy Efficiency in the EU Residential Sector. Energy Policy, 69, 73-81. https://doi.org/10.1016/j.enpol.2014.01.047

Greene, W. (2005). Fixed and Random Effects in Stochastic Frontier Models. Journal of Productivity Analysis, 23, 7-32. https://doi.org/10.1007/s11123-004-8545-1

Greening, L. A., Greene, D. L., \& Difiglio, C. (2000). Energy Efficiency and Consumption-The Rebound Effect-A Survey. Energy Policy, 28, 389-401.

https://doi.org/10.1016/S0301-4215(00)00021-5

He, L. Y., \& Huang, G. (2020). Processing Trade and Energy Efficiency: Evidence from Chinese Manufacturing Firms. Journal of Cleaner Production, 276, Article ID: 122507. https://doi.org/10.1016/j.jclepro.2020.122507 
Huang, J., \& Chen, X., (2020). Domestic R\&D Activities, Technology Absorption Ability, and Energy Intensity in China. Energy Policy, 138, Article ID: 111184. https://doi.org/10.1016/j.enpol.2019.111184

Huang, J., Hao, Y., \& Lei, H. (2018). Indigenous versus Foreign Innovation and Energy Intensity in China. Renewable and Sustainable Energy Reviews, 81, 1721-1729. https://doi.org/10.1016/j.rser.2017.05.266

IEA (International Energy Agency) (2009). Progress with Implementing Energy Efficiency Policies in the G8. Paris: International Energy Agency.

Jin, J., He, R., Kuang, F., Wan, X., \& Ning, J. (2019). Different Sources of Rural Household Energy Consumption and Influencing Factors in Dazu, China. Environmental Science and Pollution Research, 26, 21312-21320. https://doi.org/10.1007/s11356-019-05439-w

Keho, Y. (2016). What Drives Energy Consumption in Developing Countries? The Experience of Selected African Countries. Energy Policy, 91, 233-246. https://doi.org/10.1016/j.enpol.2016.01.010

Li, K., \& Lin, B. (2018). How to Promote Energy Efficiency through Technological Progress in China? Energy, 143, 812-821. https://doi.org/10.1016/j.energy.2017.11.047

Li, W., Zhao, T., Wang, Y., Zheng, X., \& Yang, J. (2019). How Does Foreign Direct Investment Influence Energy Intensity Convergence in China? Evidence from PrefectureLevel Data. Journal of Cleaner Production, 219, 57-65. https://doi.org/10.1016/j.jclepro.2019.02.025

Lin, B., \& Moubarak, M. (2014). Estimation of Energy Saving Potential in China's Paper Industry. Energy, 65, 182-189. https://doi.org/10.1016/j.energy.2013.12.014

Lundgren, T., Marklund, P. O., \& Zhang, S. (2016). Industrial Energy Demand and Energy Efficiency-Evidence from Sweden. Resource and Energy Economics, 43, 130-152. https://doi.org/10.1016/j.reseneeco.2016.01.003

Mbaka, C. K., Muiruri, P., Obiero, K., \& Kisaka, M. O. (2016). An Evaluation of GridBased Rural Electrification Adoption Dynamics in Meru-South Sub-County. International Journal of Energy and Statistics, 4, Article ID: 1650010. https://doi.org/10.1142/S2335680416500101

Narasimha Rao, M., \& Reddy, B. S. (2007). Variations in Energy Use by Indian Households: An Analysis of Micro Level Data. Energy, 32, 143-153. https://doi.org/10.1016/j.energy.2006.03.012

Pablo-Romero, M. del P., \& Sánchez-Braza, A. (2015). Productive Energy Use and Economic Growth: Energy, Physical and Human Capital Relationships. Energy Economics, 49, 420-429. https://doi.org/10.1016/j.eneco.2015.03.010

Rafindadi, A. A. (2016). Does the Need for Economic Growth Influence Energy Consumption and $\mathrm{CO}_{2}$ Emissions in Nigeria? Evidence from the Innovation Accounting Test. Renewable and Sustainable Energy Reviews, 62, 1209-1225.

https://doi.org/10.1016/j.rser.2016.05.028

Romer, P. (1990). Endogenous Technological Change. Journal of Political Economy, 98, S71-S102. https://doi.org/10.1086/261725

Romer, P.M. (1994). The Origins of Endogenous Growth. Journal of Economic Perspectives, 8, 3-22. https://doi.org/10.1257/jep.8.1.3

Salim, R., Yao, Y., \& Chen, G. S. (2017). Does Human Capital Matter for Energy Consumption in China? Energy Economics, 67, 49-59.

https://doi.org/10.1016/j.eneco.2017.05.016

Sarkodie, S. A., Adams, S., Owusu, P. A., Leirvik, T., \& Ozturk, I. (2020). Mitigating 
Degradation and Emissions in China: The Role of Environmental Sustainability, Human Capital and Renewable Energy. Science of the Total Environment, 719, Article ID: 137530. https://doi.org/10.1016/j.scitotenv.2020.137530

Sequeira, T., \& Santos, M. (2018). Education and Energy Intensity: Simple Economic Modelling and Preliminary Empirical Results. Sustain, 10, Article No. 2685. https://doi.org/10.3390/su10082625

Sianesi, B., \& Van Reenen, J. (2003). The Returns to Education: Microeconomics. Journal of Economic Surveys, 17, 157-200. https://doi.org/10.1111/1467-6419.00192

Sineviciene, L., Sotnyk, I., \& Kubatko, O. (2017). Determinants of Energy Efficiency and Energy Consumption of Eastern Europe Post-Communist Economies. Energy \& Environment, 28, 870-884. https://doi.org/10.1177\%2F0958305X17734386

Solarin, S. A. (2020). Towards Sustainable Development in Developing Countries: Aggregate and Disaggregate Analysis of Energy Intensity and the Role of Fossil Fuel Subsidies. Sustainable Production and Consumption, 24, 254-265.

https://doi.org/10.1016/j.spc.2020.07.011

Sun, H., Edziah, B. K., Kporsu, A. K., Sarkodie, S. A., \& Taghizadeh-Hesary, F. (2021a). Energy Efficiency: The Role of Technological Innovation and Knowledge Spillover. Technological Forecasting and Social Change, 167, Article ID: 120659. https://doi.org/10.1016/j.techfore.2021.120659

Sun, H., Edziah, B. K., Song, X., Kporsu, A. K., \& Taghizadeh-Hesary, F. (2020a). Estimating Persistent and Transient Energy Efficiency in Belt and Road Countries: A Stochastic Frontier Analysis. Energies, 13, Article No. 3837. https://doi.org/10.3390/en13153837

Sun, H., Edziah, B. K., Sun, C., \& Kporsu, A. K. (2021b). Institutional Quality and Its Spatial Spillover Effects on Energy Efficiency. Socio-Economic Planning Sciences, Article ID: 101023. (In Press)

Sun, H., Edziah, B. K., Sun, C., \& Kporsu, A. K. (2019). Institutional Quality, Green Innovation and Energy Efficiency. Energy Policy, 135, Article ID: 111002. https://doi.org/10.1016/j.enpol.2019.111002

Sun, H., Kporsu, A. K., Taghizadeh-Hesary, F., \& Edziah, B. K. (2020b). Estimating Environmental Efficiency and Convergence: 1980 to 2016. Energy, 208, Article ID: 118224. https://doi.org/10.1016/j.energy.2020.118224

Wang, Q., \& Li, R. (2016). Drivers for Energy Consumption: A Comparative Analysis of China and India. Renewable and Sustainable Energy Reviews, 62, 954-962. https://doi.org/10.1016/j.rser.2016.04.048

Wurlod, J. D., \& Noailly, J. (2018). The Impact of Green Innovation on Energy Intensity: An Empirical Analysis for 14 Industrial Sectors in OECD Countries. Energy Econ, 71, 47-61. https://doi.org/10.1016/j.eneco.2017.12.012

Yao, Y., Ivanovski, K., Inekwe, J., \& Smyth, R. (2019). Human Capital and Energy Consumption: Evidence from OECD Countries. Energy Economics, 84, Article ID: 104534. https://doi.org/10.1016/j.eneco.2019.104534

Zhang, J., \& Kotani, K. (2012). The Determinants of Household Energy Demand in Rural Beijing: Can Environmentally Friendly Technologies be Effective? Energy Economics, 34, 381-388. https://doi.org/10.1016/j.eneco.2011.12.011 